\title{
UM ESTUDO DO HUMOR DA AMA DE ROMEU JULIETA NAS TRADUÇÕES DE BÁRBARA HELIODORA E BEATRIZ VIÉGAS-FARIA
}

\author{
A STUDY ON ROMEO AND JULIET'S NURSE'S HUMOR IN BÁRBARA \\ HELIODORA'S AND BEATRIZ VIÉGAS-FARIA'S TRANSLATIONS
}

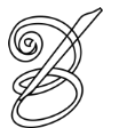 \\ Tiago Marques LUIZ ${ }^{1}$ \\ Universidade Federal de Uberlândia \\ Camila Paula CAMILOTTI ${ }^{2}$ \\ Universidade Tecnológica Federal do Paraná.
}

\begin{abstract}
Resumo: Este trabalho tem como propósito apresentar um estudo comparativo de duas traduções brasileiras da peça Romeu e Julieta, de William Shakespeare, com enfoque no Ato 1, Cena 3, na qual constam as falas da personagem secundária Ama, que são carregadas de comicidade e certo teor sexual. Para esse propósito, serão feitas algumas breves considerações sobre o elo entre o humor e a tradução e sobre essa personagem secundária, cujas características cômicas se assemelham ao clown, figura bastante recorrente na literatura dramática medieval e que foi transposta para o palco renascentista. As duas traduções utilizadas para este trabalho analítico são de Bárbara Heliodora (1997) e Beatriz Viégas-Faria (2016). A análise demonstra que ambas as tradutoras buscaram, cada uma à sua maneira, lidar com a comicidade da personagem de modo criativo, sem perder de vista o teor cômico presente no texto-fonte.
\end{abstract}

Palavras-chave: Tradução Literária. William Shakespeare. Humor. Ama. Romeu e Julieta.

Abstract: This paper aims to present a comparative study of two Brazilian translations of William Shakespeare's Romeo and Juliet, focusing on Act 1, Scene 3, where are included the lines of the Nurse, loaded with comedy and a certain sexual content. For this purpose, a few brief considerations will be made on the link between humor and translation, and on this secondary character, whose comic features resemble the clown, a figure quite recurrent in medieval dramatic literature and transposed to the Renaissance stage. The two translations used for this analytical work are Bárbara Heliodora's and Beatriz Viégas-Faria's (2016) (1997). The analysis demonstrates that both translators sought, each one in their own way, to deal with the comedy of the character in a creative way, without losing sight of the comic content presented in the source text.

Keywords: Literary Translation. William Shakespeare. Humor. Nurse. Romeo and Juliet.

RECEBIDO EM: 02/04/2018

ACEITO EM: 25/08/2018

PUBLICADO EM: dezembro 2018

LUIIZ, CAMILOTTI. Um estudo do humor da Ama de Romeu Julieta nas traduções de Bárbara Heliodora e Beatriz Viégas-Faria

Belas Infiéis, v. 7, n. 2, p. 9-26, 2018. DOI: 10.26512/belasinfieis.v7i2.12225 


\section{Introdução}

riqueza da obra de Shakespeare reside em seu manuseio da linguagem, por meio de
artifícios retóricos, tais como a inversão de frases, a estrutura sintática ${ }^{3}$, alguns
neologismos, alusões, imagens ${ }^{4}$ e figuras de linguagem ${ }^{5}$. Além disso, o autor se destaca pela construção e elaboração de personagens e dos enredos de suas peças. Em relação ao processo de tradução linguística de suas obras, o texto de Shakespeare traz ao tradutor questões complexas tanto de teor linguístico, cultural, como também social e porventura artístico (em caso de tradução teatral).

De acordo com a proposta de Patrice Pavis (2008), o texto dramático, quando traduzido para o teatro, passa por quatro fases de concretização, sendo T0 o correspondente ao texto original, T1 o que corresponde à concretização linguística desse texto-fonte, T2 o que corresponde a concretização dramatúrgica, T3 a sua tradução para o palco e T4 o que corresponde a concretização da recepção, ou seja, é quando o texto junto aos outros elementos do teatro, tais como luz, música, figurino, cenário, é recebido pelo espectador no momento da mise-en-scène. No trabalho proposto, estamos analisando somente a tradução linguística do texto shakespeariano, ou seja, a T1, e para que a tradução seja transferida para o palco, ela deverá passar pelas outras demais fases. Um desafio para um tradutor é o de transpor para a sua tradução o humor que se encontra no texto original, ou seja, trabalhar com "recursos textuais e discursivos passíveis de gerar o riso presentes no original e como estes elementos foram transpostos nas traduções" (LUIZ, 2013, p. 11), seja nos textos de Shakespeare ou em qualquer outro texto que contenha carga cômica.

A tradução é uma operação que envolve as inúmeras linguagens e, como todo e qualquer processo de tradução, independente do suporte textual - teatro, literatura, quadrinho e dança, por exemplo, o texto traduzido está sujeito a perdas e compensações (ECO, 2007; LUIZ, 2013; BARANCZAK, 1992), como também o tradutor não se isenta das críticas em relação ao seu ofício, sejam elas favoráveis ou não. No caso específico da linguagem humorística, Adauri Brezolin (1997) diz que traduzir textos humorísticos, como também as cenas do texto teatral, não é um consenso recorrente entre os tradutores e que existe nos textos humorísticos "uma concordância generalizada quanto ao fato de esse tipo de texto mostrar-se como um grande desafio aos tradutores" (BREZOLIN, 1997, p. 16, colchete nosso).

Para lidar com a tradução de textos cômicos e/ou irônicos, o tradutor precisará utilizar, em grande medida, a sua criatividade, sua competência linguística e a sua bagagem cultural, na 
qual se considera a gama dos estereótipos ${ }^{6}$ e possíveis equivalentes. Em relação à competência linguística, ressalta-se o modo como o texto apresenta as figuras de linguagens - como a ironia e os jogos de palavras - recorrentes no humor. A criatividade se respalda no esforço de trazer o sentido cômico do texto-fonte para o texto-alvo, uma vez que o sentido proposto nem sempre terá equivalente na língua a ser traduzida, principalmente em se tratando de trocadilhos. Desta forma, recorremos a uma articulação entre o humor e a linguagem, partindo da seguinte premissa:

A opacidade da linguagem condensa múltiplas possibilidades formais que permitem seu emprego cômico, aproveitando os aspectos rítmicos, as analogias fonéticas, a ambigüidade dos significantes. Quando essas operações (que se assemelham à brincadeira infantil de manejar palavras como parte de um quebra-cabeça, mas sem nenhuma ingenuidade) têm apenas a si próprias como fim, conseguem macular a certeza de que a linguagem seja límpida transmissora de ideias que a razão deseja. (D’ANGELI; PADUANO, 2007, p. 197)

O próprio universo dramático das peças shakespearianas está repleto de ambiguidades, trocadilhos irônicos, obscenos e espirituosos, "e a julgar pela sua recepção nas diferentes culturas-alvo, tais características estilísticas continuam a lhe ser atribuídas" (MARTINS, 2016, p. 291). No viés tradutório, depara-se com a questão da equivalência, mais precisamente com a equivalência dinâmica, a qual Delia Chiaro (2014) teoriza como um tipo de correspondência disposta a produzir e dar efeito sobre o leitor "aquilo que é semelhante ao efeito causado pelo texto fonte no leitor de origem, mesmo que isso signifique renunciar à semelhança formal ${ }^{7}$, (CHIARO, 2014, p. 1396), propondo alterações drásticas do humor-fonte para que ele seja recebido pelo leitor e/ou espectador do humor-alvo.

A respeito do humor das peças de Shakespeare, Márcia do Amaral Peixoto Martins tece a problemática de que se os próprios jogos de palavras representavam um desafio na própria língua inglesa renascentista, consequentemente esse artifício é ainda mais desafiador nas questões de tradução para outra língua, quando é preciso encontrar "equivalentes formais e estilísticos na língua de chegada, sob pena de se des-shakespearianizar Shakespeare" (MARTINS, 2016, p. 288).

Levando em consideração as premissas apontadas acima, este trabalho busca observar as falas da Ama, personagem secundária responsável por gerar certa comicidade no enredo da peça Romeu e Julieta, em duas traduções brasileiras: a de Barbara Heliodora (1997) e de Beatriz Viegas-Faria (2016). A Ama é vista como a confidente do casamento secreto dos jovens 
apaixonados, como também é uma segunda mãe para Julieta, pois como ela diz no próprio texto, foi ela quem amamentou e cuidou da jovem quando essa era um bebê. As suas falas são marcadas pelo uso da prosa, sendo então um registro de fala coloquial, uma vez que segundo a tradutora Beatriz Viégas-Faria (s/d), cada estrutura poética usada pelos personagens no texto é um molde da posição em que personagem ocupa.

No tocante à linguagem cômica da personagem, a Ama é carregada de trocadilhos de teor sexual, tanto na cena em que ela e a Senhora Capuleto convencem a jovem de se casar com Páris, como também ridiculariza Romeu no Ato 3, Cena 3, por Julieta estar sofrendo duplamente - pela morte de seu primo Teobaldo e pelo exílio de Romeu: "Pelo bem de Julieta, fique em pé. Quem fica assim não levanta mais nada!" (SHAKESPEARE, 1997, p. 117-118), onde o verbo levantar remete ao estado teso e ereto do jovem.

As traduções serão analisadas e cotejadas no Ato I, Cena 3 da referida peça, onde nos deparamos com falas da Ama carregadas de comicidade e certo teor sexual. O interesse principal é observar como as tradutoras lidaram com a comicidade presente nas falas da personagem nessa cena em particular e, para isso, tecemos considerações sobre o elo entre a

12 tradução e o humor, como também as características da personagem Ama com o clown $^{8}$, figura cômica recorrente no teatro e na literatura Renascentista (STEVENS; MUTRAN, 1988; WILES, 2005). A origem do clown remete, segundo Andrew Cecil Bradley (1905), às peças religiosas medievais conhecidas como moralidades:

O bobo ou o palhaço teatral [...] foi um julgamento dolorido para o poeta e espectador cultos no dia de Shakespeare. Ele proveio das peças das moralidades, e foi amado pelos espectadores. Seus palavrões, suas canções, suas danças, seus júbilos, muitas vezes impuros, os encantaram e fizeram algo para fazer o drama, como o vulgar, pobre ou rico, como ele, um entretenimento variado ${ }^{9}$. (BRADLEY, 1905, p. 310).

No processo comparativo, iremos nos ater ao glossário de Gordon Williams (1997) intitulado A glossary of Shakespeare's sexual language e algumas considerações de Stanley Wells (2010) em sua obra Shakespeare, Sex and Love, como também trazer as considerações de Mary Bly (2001), na coletânea editada por Caterine M. S. Alexander e Stanley Wells (2001) intitulada Shakespeare and Sexuality.

\section{Tradução, Shakespeare e Humor}

Humor corresponde ao que Patrick Zabalbeascoa conceituou como um elemento comunicativo cuja intenção é a "de produzir o riso ou graça (no sentido de ser cômico) nos 
destinatários do texto ${ }^{10}$ " (ZABALBEASCOA, 2001, p. 255). Devido ao amplo campo semântico, a linguagem humorística implica, tanto por parte do leitor quanto do tradutor, o reconhecimento das figuras de linguagem. No caso específico das peças de Shakespeare, é necessário o acompanhamento de suportes bibliográficos como dicionários, edições anotadas e comentadas, glossários e comentários no texto-fonte.

A respeito da questão da traduzibilidade do humor, Jeroen Vandaele (2010) evoca Roland Diot (1989), cujas palavras confirmam que traduzir humor é tão desesperador quanto traduzir poesia, uma vez que o humor não segue normas estruturais, divagando entre os demasiados tipos de textos. Além disso, Vandaele (2010) ressalta que a traduzibilidade do humor está vinculada a aspectos linguísticos e culturais:

Por um lado, qualquer falha na tradução será, portanto, muito visível: é óbvio que o tradutor falhou quando ninguém ri do humor traduzido. Por outro lado, o tradutor de humor tem que lidar com o fato de que as "regras", as "expectativas", as "soluções" e os acordos de "jogo social" são muitas vezes específicos de grupos ou culturas ${ }^{11}$ (VANDAELE, 2010, p. 149).

É importante que, ao traduzir especificamente o texto humorístico, o tradutor seja capaz de solucionar - em maior ou menor escala - a reescrita do novo texto cômico, o que lhe demanda certo grau de criatividade, uma vez que há grande diferença entre as línguas e as culturas envolvidas. De acordo com Delia Chiaro, dada a circunstância do descontrole, ou seja, a não-regulação do fenômeno da tradução do humor verbal, a equivalência ao texto original "pode ser melhor relegada para o segundo lugar, por trás das tentativas de um texto recriado reconhecido como humorístico para destinatários alvo ${ }^{12 "}$ (CHIARO, 2014, p. 1394).

Assim, chegamos à chamada "equivalência humorística", termo cunhado por Javier Muñoz-Basols e Micaela Muñoz-Calvo, que compreende um processo consciente da capacidade de o tradutor "(re)produzir um componente ou efeito humorístico, ou de entretenimento, no texto meta como objetivo de que o receptor esteja exposto e perceba tal efeito $^{13}$ " (MUÑOZ-BASOLS, MUÑOZ-CALBO, 2015, p. 161). Em outras palavras, a ausência do referido componente culminará no apagamento do sentido do texto e, consequentemente, o propósito comunicativo não se estabelecerá entre o tradutor e autor, e tradutor e público.

Além do mais, esse fenômeno, segundo os autores, se manifesta das mais variadas formas e expressões artísticas: como o próprio tom da voz, a imitação de um sotaque, gestos faciais e corporais, que vão demandar competência cognitiva do interlocutor ou receptor de um texto. Como o aspecto cognitivo é crucial para a recepção da mensagem, os autores salientam 
que determinados elementos concretos da cultura de partida - como os aspectos culturais de uma sociedade, por exemplo, tais como idioletos, variações linguísticas, sotaques - podem não ter um equivalente na cultura de chegada. Portanto, tendo em mente o teor da comunicação entre emissor e seus destinatários, o primeiro passo que o tradutor deve dar é "reconhecer a especificidade linguística e cultural do texto humorístico para [...] determinar como se pode traduzir ou reconfigurar os elementos próprios do ato comunicativo ${ }^{14}$ " (MUÑOZ-BASOLS, MUÑOZ-CALBO, 2015, p. 163).

Neste trabalho, tem-se um texto dramático, cuja escrita visa à performance no palco e, mesmo estando suscetível a mudanças de maior ou menor grau, nunca é/será simples de se representar, pois é necessária uma gama de leituras por parte dos agentes do teatro, diretor, ator, produtor, sonoplasta, entre outros, desse texto para chegar ao texto-final, que é a performance, e esta não necessariamente se aplica à sua tradução literária.

Cada leitor tem uma interpretação diferente de um mesmo texto e, no caso do teatro, nem todos os espectadores compartilharão da mesma interpretação, como também não irão depreender o que lhes foi transmitido no palco, pois a tradução teatral partiu segundo a 14 concepção dos produtores do espetáculo. No que tange o humor em cenas coletivas e sua representação no palco, Tiago Marques Luiz pondera o seguinte:

O humor, quando transposto para o palco, é colocado de forma mais leve na cena e até nos trejeitos que o ator estuda para fazer o personagem. Muitos leigos falam que fazer cenas de humor é fácil e não precisa estudar. Mero equívoco: interpretar humor requer muito estudo para o ator. Em cena coletiva, onde há vários atores em cena, é muito mais difícil ainda. Existe um trabalho bem mais rigoroso e muitas horas de ensaios até que as cenas sejam sincronizadas juntamente ao tempo de fala dos atores (LUIZ, 2013, p. 26).

Luiz ressalta justamente a questão da sincronia do tempo de ensaio até o tempo final da performance, tempo esse que pode ser visto como uma espécie de tradução, uma vez que são feitos os vários ajustes no tempo do texto-matriz até chegar à sua versão cênica e cronológica definitiva para que os atores possam corresponder e interpretar suas falas sem se desvencilhar do teor original da matriz cômica que lhes foi entregue.

Por isso, dentro da esfera teatral, existe um leque de palavras e de gestos para que a comicidade seja levada ao espectador e suscite a gargalhada na plateia que assiste. Se porventura uma passagem cômica não foi contemplada ou não foi compreendida pelos espectadores, o espetáculo se compromete. Interpretar o humor no palco é uma tarefa complexa,

LUIIZ, CAMILOTTI. Um estudo do humor da Ama de Romeu Julieta nas traduções de Bárbara Heliodora e Beatriz Viégas-Faria

Belas Infiéis, v. 7, n. 2, p. 9-26, 2018. DOI: 10.26512/belasinfieis.v7i2.12225 
pois demanda do ator um grande preparo para a interpretação daquela passagem e saber transmitir a comicidade da cena para os espectadores é uma contracorrente; se a interpretação não surte efeito, o espetáculo recebe críticas severas e, da outra margem, o espectador tem a expectativa arruinada, pois o objetivo de fazer o espectador rir não foi alcançado.

Portanto, é necessário que todos os envolvidos no espetáculo saibam transmitir a comicidade presente no texto, pois as passagens cômicas podem surtir três efeitos para o espectador: a) ser realmente cômica em sua textualidade, b) ser patética ou acentuar a tragicidade da cena em que ela se encontra, ou c) aliviar a tensão, para que o espectador tenha pausa suficiente para aguardar as próximas cenas pesadas que sucederão, conforme o texto de Arthur Huntington Nason (1906), traduzido recentemente (LUIZ, 2017).

Além da visualidade cênica em questão, existe um componente crucial para a tradução do elemento humorístico: o seu sentido. Millôr Fernandes adverte que é inconcebível o tradutor "explicitar aquilo que o autor quer deixar implícito, esclarecer aquilo que ele quer deixar misterioso, engrossar o humor que é fino ou tornar sutil o humor que é grosso" (FERNANDES, 1989, p. 78). Se o tradutor não segue tal advertência, a sua tradução pode não ser compreendida pelo leitor-receptor e não articulará com as próximas cenas do texto dramático, uma vez que a narrativa dramática enseja uma correspondência entre as falas dos atores/personagens. Quando o desencadeamento de uma cena cômica não ocorre, os atores terão que improvisar para que a recepção da comicidade não se perca.

Feitas essas considerações, partimos para a personagem da Ama, que corresponde ao que se chama de clown, uma personagem herdada da tradição medieval, cuja explicação foi apresentada anteriormente.

\section{A Ama de Romeu e Julieta}

Situado em um período bastante favorável, Shakespeare foi capaz de sintetizar e comungar a herança clássica e medieval com o advento do humanismo em sua arte, onde os inúmeros personagens que fazem parte do seu universo "nos fa[zem] perceber a base de relações humanas, lutas pelo poder, afetos, sentimentos e a precariedade do ser humano diante de sua condição material e espiritual" (SILVA, 2013, p. 85, colchetes nossos). A riqueza da dramaticidade consiste em um ponto de partida: o autor, cujo manuseio da linguagem, além das categorias do tempo, espaço e ação, se reflete nos personagens e suas ações no decorrer da narrativa dramática, e como bem pontua Jan Kott: 
[....] nenhum personagem, nenhuma situação ou ação preexiste ao momento em que o autor encontra as palavras certas para expressá-los em seu diálogo - cada personagem de uma peça é constituído, exclusivamente, pela soma de suas falas; cada situação é criada pela sequência dessas falas definidoras de temperamentos, de atitudes diferentes e geralmente conflitantes. (KOTT, 2003, p. 13-14)

A Ama é uma personagem secundária na peça, cuja fala apresenta-se, quase sempre, em prosa e é marcada por um humor escancarado, com trocadilhos que possuem, na maioria das vezes, um teor sexual, o que, no contexto de Shakespeare, era visto como algo imoral para os costumes da época. Vale mencionar que essa linguagem rudimentar utilizada pela Ama é uma estratégia shakespeariana de demonstrar a posição social que a personagem pertencia, pois de acordo com a tradutora e pesquisadora Beatriz Viégas-Faria (s/d), enquanto as personagens nobres falavam em verso, as personagens secundárias - como os guardas e os criados - falavam em prosa, como é o caso da referida personagem de Romeu e Julieta, cuja característica provém de uma personagem medieval conhecida como clown (STEVENS; MUTRAN, 1988 ; WILES, 2005).

Os clowns de Shakespeare são geralmente personagens de classe secundária, cuja 16 inteligência supera as pessoas de maior reputação social. Nesse sentido, eles são muito semelhantes aos verdadeiros bobos e piadistas da época, mas suas características são bastante realçadas para efeito teatral. Esse personagem simples, em consonância com as ideias revolucionárias de Shakespeare sobre o teatro, veio a se tornar um personagem complexo, destacando questões mais importantes, fora dos limites estreitos da moral exemplar.

Os clowns shakespearianos abordam temas como amor e identidade pessoal. A função do clown era, portanto, reduzir a pretensão intelectual e chamar a atenção para o que Mikhail Bakhtin chamou de "estrato físico material mais baixo" (BAKHTIN, 1999, p. 277), isto é, o mundo abaixo da cintura e a esfera do apetite humano, permitindo assim ao espectador distanciar-se de uma atividade e um discurso de alto nível. No caso do humor da Ama, uma personagem intrometida e obscena, ele pode ser sugerido ou explícito na maioria das vezes.

Na peça Romeu e Julieta, a personagem em questão utiliza uma linguagem vulgar, característica marcante de personagens inferiores à sociedade nobre. Contudo, embora no princípio aristotélico a personagem cômica seja vista como rebaixada e ridicularizada por causa de suas falhas e vícios (BENDER, 1996, p. 34), neste trabalho ela é valorizada, devido à sua responsabilidade no decorrer da trama, por atuar como confidente do casal e uma segunda mãe para a protagonista - daí a sua responsabilidade na peça -, e para que o humor surja, é necessário que o ator/atriz que interpreta o personagem cômico seja capaz de convencer a plateia. 
E possivelmente a plateia se deleitava com cenas sugestivas de teor sexual nos diálogos dos personagens, uma vez que a riqueza do trocadilho reside no fato de ser "um meio de contornar tabus, assim como os eufemismos, que desempenham um jogo semelhante de esconde-esconde com o ouvinte/leitor ${ }^{15 "}$ (BLY, 2001, p. 53).

A passagem cômica que escolhemos para esta análise tradutória e comparativa está na Cena 3, Ato 1 da peça shakespeariana, onde a Ama tem um diálogo fervoroso com Julieta a respeito do aniversário da jovem. Os trocadilhos da Ama são carregados de certa conotação sexual em passagens sérias, como no Ato II, Cena V, onde Julieta questiona a Ama sobre a resposta de Romeu para o casamento secreto e esta lhe responde que sim e sexualiza a aparência do rapaz. Isso também ocorre no Ato III, Cena III, onde ela diz a Romeu para consolar Julieta pela perda de Teobaldo, uma vez que consolar implica conotação sexual e por ser sentenciado ao exílio, e muitas expressões, cujo sentido pode parecer inocente, possuem um teor obsceno em determinados diálogos e situações, como veremos a seguir. Na tabela abaixo, as siglas TYU referem-se ao texto de partida, publicado pela Yale University Press, TBH para a tradução de Bárbara Heliodora e TBV para a tradução de Beatriz Viégas-Faria. No quadro 1, pode-se ter uma primeira noção do tipo de linguagem usada pela Ama:

Quadro 1 - Início do Ato I, Cena 3

\begin{tabular}{|c|c|c|}
\hline TYU (2004, p. 30) & TBH (1997, p. 42) & TBV (2016, p. 32-33) \\
\hline NURSE & Ama & Ama \\
\hline $\begin{array}{l}\text { Yes, madam. Yet I cannot choose } \\
\text { but laugh. } \\
\text { To think it should leave crying and } \\
\text { say "ay." } \\
\text { And yet, I warrant, it had upon its } \\
\text { brow. } \\
\text { A bump as big as a young } \\
\text { cockerel's stone, } \\
\text { A perilous knock, and it cried } \\
\text { bitterly. } \\
\text { "Yea," quoth my husband, "Fall'st } \\
\text { upon thy face? } \\
\text { Thou wilt fall backward when thou } \\
\text { comest to age. } \\
\text { Wilt thou not, Jule?" It stinted and } \\
\text { said "ay." }\end{array}$ & $\begin{array}{l}\text { Sim, senhora, mas é mesmo de rir } \\
\text { Ela não chora, mais, e dizer: "É." } \\
\text { E eu garanto que, bem aqui na } \\
\text { testa, } \\
\text { Tinha um inchaço que até parecia } \\
\text { Culhão de galo, e que doía muito. } \\
\text { E ele disse: "Cai assim, de cara? } \\
\text { Quando crescer só vai cair de } \\
\text { costas, } \\
\text { Não é, Julinha?" } \\
\text { E ela disse: "É." }\end{array}$ & $\begin{array}{l}\text { Sim, senhora. E, no entanto, não } \\
\text { consigo parar de rir, só de pensar } \\
\text { que ela parou de chorar e disse } \\
\text { Combinado. E posso lhe garantir, } \\
\text { senhora, ela tinha na testa um galo } \\
\text { tão grande como um colhão de } \\
\text { galo, um tremendo calombo; e ela } \\
\text { abriu o berreiro! Então, disse meu } \\
\text { marido, caíste de cara no chão? } \\
\text { Quando fores maiorzinha e } \\
\text { souberes mais do mundo, cairás de } \\
\text { costas. Combinado, Jule?, e ela } \\
\text { controlou o choro e disse } \\
\text { Combinado. }\end{array}$ \\
\hline
\end{tabular}

Elaboração: Camila Paula Camilotti e Tiago Marques Luiz

A anedota apresentada pela Ama é capaz de deixar a bochecha de uma adolescente corada de vergonha, mas por ser uma antiga funcionária da casa, suas excentricidades são, pelo menos, toleradas pela plateia. O comentário do marido sobre Julieta cair de costas quando ela 
atinge certa idade, parece fazer alusão à Julieta um dia tendo relações sexuais. Seu comentário, portanto, mostra que Julieta era vista como a objetificação potencial de sexualidade e casamento desde criança. Em termos gerais, o destino de Julieta de algum dia contrair matrimônio foi estabelecido desde o nascimento.

Nota-se que os sintagmas "young cockrel's stone" e "perilous knock" remetem ao testículo do galo e ao ato sexual, como também "fall backward" implica a perda da virgindade e o primeiro contato sexual da jovem. As duas traduções mantiveram o sentido obsceno do primeiro sintagma, uma vez que "colhão de galo" - uma típica uva de Portugal muito usada na fabricação de vinhos - se assemelha a um testículo humano. Enquanto que no segundo sintagma, a primeira tradução soube interligar o sentido sexual - prazer e dor, na segunda tradução prevaleceu o sentido denotativo, isto é, o inchaço por conta da queda. O terceiro sintagma - "fall backward" - manteve a ambiguidade sugerida nas duas traduções.

No próximo trecho, a Senhora Capuleto conversa com Julieta sobre a possível empolgação da jovem em relação ao casamento e a jovem responde que é uma honra, mas que não cogita isso em sua tenra idade. A Ama intervém no diálogo entre mãe e filha, conforme o 18 quadro 2:

Quadro 2 - A sexualidade do corpo

\begin{tabular}{|l|l|l|}
\hline \multicolumn{1}{|c|}{ TYU (2004, p. 31) } & \multicolumn{1}{|c|}{ TBH (1997, p. 43) } & \multicolumn{1}{c|}{ TBV (2016, p. 33) } \\
\hline NURSE & AMA & AMA \\
$\begin{array}{l}\text { An honor? Were not I thine only } \\
\text { nurse, }\end{array}$ & $\begin{array}{l}\text { Uma honra. Não fosse eu sua ama, } \\
\text { E diria que o juízo vem do peito. } \\
\text { I would say thou hadst sucked } \\
\text { wisdom from thy teat. }\end{array}$ & $\begin{array}{l}\text { Uma honra! Não fosse eu tua única } \\
\text { ama, e diria que mamaste } \\
\text { sabedoria de teu próprio peito. }\end{array}$ \\
\hline
\end{tabular}

Elaboração: Camila Paula Camilotti e Tiago Marques Luiz

A Ama explicita uma noção vulgar em assuntos de mulheres, porém é visível uma familiaridade com Julieta, pois foi ela quem criou a menina, amamentando-a. Além disso, vemos a Ama realçar outro elemento sexual; se Julieta não conquistar Páris com sua sabedoria e juízo - como deveria ser uma jovem renascentista -, o conquistaria pelos seios, uma vez que na tradição literária, os seios são sempre presentes, pois além de serem o grande atrativo do corpo feminino, são capazes de fazer o homem perder o raciocínio. E como Julieta está entrando na pré-adolescência, seu corpo irá se desenvolver. Dito de outra forma, se não o conquistar pela mente, conquiste-o pela carne. 
Harold C. Goddard questiona se existe uma maldição mais antiga que a sensualidade e seus derivados, pelo fato de que muitos críticos repudiam a Ama "como uma velha grosseira, cuja loquacidade nos faz rir, não consegue assimilar a profundidade de sua depravação ${ }^{16}$ " (GODDARD, 2004, p. 88). Como ela é uma senhora de idade, a sua experiência de vida a faz ser uma experiente no tocante ao aspecto sexual. Além disso, críticos puritanos que censuraram um artefato tão precioso como a linguagem vulgar não seriam capazes de ver a performance de uma senhora de idade e seus atrativos.

No próximo trecho, vemos a mãe e a Ama falando de Páris, um pretendente para Julieta, realçando sua beleza e feições:

Quadro 3 - A sexualização de Páris

\begin{tabular}{|l|l|l|}
\hline \multicolumn{1}{|c|}{ TYU (2004, p. 31) } & \multicolumn{1}{|c|}{ TBH (1997, p. 43) } & \multicolumn{1}{c|}{ TBV (2016, p. 33) } \\
\hline $\begin{array}{l}\text { Verona's summer hath not such a } \\
\text { flower }\end{array}$ & SRA. CAPULETO & LADY CAPULETO \\
NURSE & AMA fina flor do verão de Verona. & $\begin{array}{l}\text { O verão de Verona está por ver } \\
\text { frutos como esse, pleno de } \\
\text { sementes. }\end{array}$ \\
Nay, he's a flower - a very flower. & Uma flor, mesmo; ele é uma flor. & $\begin{array}{l}\text { AMatamente, um fruto. Na verdade, } \\
\text { um fruto carregado de sementes. }\end{array}$ \\
\hline
\end{tabular}

Elaboração: Camila Paula Camilotti e Tiago Marques Luiz

A Senhora Capuleto afirma que não há ninguém para rivalizar com Páris, tanto em aparência como em qualidade, porém a fala da Ama sugere que, por Páris ser uma metafórica flor, ele também é experiente e mais maduro, dando a entender que o jovem é mais velho que a protagonista. Portanto, em termos de metáfora humorística, Julieta é um brotinho prestes a desabrochar, em comparação com a idade e a experiência do rapaz, uma vez que a metáfora da flor pode corresponder à conotação do frescor da virgindade, segundo Gordon (1997), e também à experiência sexual de Páris.

A primeira tradução preservou a ambiguidade em 'fina flor', compreendendo 'fina' no sentido denotativo de condição física e de condição financeira, uma vez que Páris é um nobre, enquanto 'flor' implica duas acepções: flor como metáfora de amadurecimento sexual e social, e flor como sinônimo de beleza.

A segunda tradução, por sua vez, substituiu 'flor' por 'fruto', cujo sentido conotativo é explícito na fala das duas personagens. Portanto, a segunda tradução foi mais concisa e criativa em relação ao sentido sexual nesta passagem, cabendo frisar que as traduções de TBV são bem 
mais longas que a respectiva passagem no texto original, o que não compromete o sentido proposto no texto-fonte.

Após a sexualização de Páris, a Senhora Capuleto chama a atenção da filha, por meio de metáforas, para convencê-la de que o jovem é um bom partido, porém a última sentença compromete o desfecho:

Quadro 4 - Casamento metafórico

\begin{tabular}{|l|l|l|}
\hline \multicolumn{1}{|c|}{ TYU (2004, p. 32) } & \multicolumn{1}{|c|}{ TBH (1997, p. 44) } & \multicolumn{1}{c|}{ TBV (2016, p. 34) } \\
\hline $\begin{array}{l}\text { LADY CAPULET } \\
\text { possess } \\
\text { By having him, making yourself } \\
\text { no less. }\end{array}$ & SRA. CAPULETO & $\begin{array}{l}\text { LADY CAPULETO } \\
\text { Compartilhando do que ele possui, }\end{array}$ \\
$\begin{array}{l}\text { NURSE } \\
\begin{array}{l}\text { No less? Nocê não se diminui. } \\
\text { grow by men. }\end{array}\end{array}$ & $\begin{array}{l}\text { Gostarias de com ele compartilhar } \\
\text { tudo o que ele possui, aceitando-o } \\
\text { como teu amo, ao mesmo tempo } \\
\text { em que não te diminuis? }\end{array}$ \\
\hline
\end{tabular}

Elaboração: Camila Paula Camilotti e Tiago Marques Luiz

Nesta passagem, mãe e empregada convencem - à sua maneira - a jovem de que casar com Páris será bom. Na fala da mãe, vemos a possibilidade de ascensão social da protagonista, uma vez que a mulher casada com um nobre teria maior visibilidade por conta do status do marido, apesar de Julieta pertencer à nobreza.

A Ama se vale do trocadilho "grow", tanto como crescer em ascensão social, como também na conotação de engravidar. A mulher cresce - engravida - ao se casar. A primeira tradução mantém a ambiguidade ao usar os verbos "aumentar" e "crescer", enquanto que a segunda tradução desambiguizou o sentido - "tornas-te maior".

Na passagem final, ao serem anunciadas da chegada de Páris, a Ama se despede Julieta, acreditando que ambos o casamento e o sexo levam à felicidade:

Quadro 5 - Casamento e Sexo como sinônimo de felicidade

\begin{tabular}{|c|c|c|}
\hline TYU $(2004$, p. 33) & ТВH $(1997$, p. 45) & TBV (2016, p. 35) \\
\hline NURSE & AMA & AMA \\
\hline $\begin{array}{l}\text { Go girl, seek happy nights to happy } \\
\text { days. }\end{array}$ & Com noite boa, o dia é bem melhor! & $\begin{array}{l}\text { Vai, menina, vai em busca de } \\
\text { noites felizes que acompanhem os } \\
\text { teus dias felizes. }\end{array}$ \\
\hline Exeunt & (Saem.) & (Saem.) \\
\hline
\end{tabular}

Elaboração: Camila Paula Camilotti e Tiago Marques Luiz 
Para a Ama, noites regadas à festa, música e dança resultam em dias felizes, ou seja, mulher casada com um homem rico e bonito, no caso, Julieta e Páris. As duas tradutoras souberam lidar com esse sentido implícito da fala da Ama em suas traduções e, ao compararmos com o texto original, constatamos que as duas tradutoras souberam lidar com as passagens cômicas desta cena da peça Romeu e Julieta.

A hipótese nesse processo comparativo é que, por serem de regiões diferentes - a primeira tradutora, carioca, e a segunda, gaúcha -, cada uma manejou a fala da Ama de acordo com as convenções de suas regiões. Os estereótipos são, de certa forma, elementos marcantes na construção de qualquer texto humorístico, de grande poder original e criativo, uma vez que o humor é o elemento construtor de sentido na peça, pois o riso, na condição de elemento presente na comédia e também na tragédia shakespeariana, nos permite conhecer melhor, via tradução ou transposição para outras linguagens, o estereótipo como fator motivador da graça. Portanto, o manejo do discurso do alvo estereotipado é uma forma de construir uma unidade de significado, e foi justamente o estereótipo do carioca malandro e do gaúcho viril que ecoaram nas falas da Ama nas traduções em estudo que fazem o leitor rir.

Por fim, se tivéssemos o registro de uma encenação, possivelmente veríamos que a gestualidade da Ama, junto ao código verbal utilizado por ela, seria mais cômica, pois a linguagem cênica potencializa a linguagem escrita juntamente com o cenário, a indumentária, a voz da atriz e todo o aparato que faz parte do mundo do teatro. Ambas as traduções correspondem à tipologia proposta nos Estudos da Tradução: as destinadas ao palco ${ }^{17} \mathrm{e}$ as destinadas à página ${ }^{18}$, embora não haja alguma informação nos paratextos das traduções consultadas. Cabe então ressaltar as palavras de Márcia do Amaral Peixoto Martins, que nos diz que uma tradução de Shakespeare em página não significa que ela não possa vir a ser um texto performático, embora muitas editoras procurem "vincular a publicação de uma nova tradução de peça shakespeariana à sua respectiva encenação nos palcos do país" (MARTINS, 1999, p. 16).

A partir desta concepção, corroboramos a reflexão de Susan Bassnett (BASSNETT, 1998, p. 107), na qual a combinação do texto escrito com os elementos sígnicos do teatro, os quais potencializam o espetáculo, não é somente uma tarefa do tradutor, pois além de seu conhecimento específico do campo teatral, agentes como o diretor e o dramaturgo também ressignificam o texto. No texto shakespeariano, por exemplo, é notório que certos vocábulos com significado aparentemente inocentes podem soar sexuais aos seus primeiros leitores, e 
Shakespeare pode ter ansiado que o público as depreenda, até porque a linguagem obscena integra-se a um dos os propósitos artísticos do dramaturgo inglês - ou seja, o de fazer a plateia rir.

\section{Considerações finais}

Este trabalho teve como propósito analisar as traduções de Bárbara Heliodora (1997) e Beatriz Viégas-Faria (2016), da peça shakespeariana Romeu e Julieta. Para nós, estudiosos da tradução, o bom tradutor é aquele que, embora tenha o esforço de trazer o significado pleno daquele texto que o autor criou em sua temporalidade, tenha ciência do fato de que lidar com humor e ironia é um desafio, o que lhe demanda criatividade com a linguagem, como também com a cultura em questão, uma vez que estes dois elementos - cultura e língua - estão implícitos no texto. Entretanto, como a língua é dinâmica, determinados sentidos acabaram se perdendo com o deslindar da História, e somente por meio de documentos e registros é que é possível recuperar determinado significado do texto.

No caso do texto dramático, o suporte ao qual o texto será transposto - no caso, o teatro - fará toda a diferença na percepção e recepção da matéria textual. E como todo texto-base, vários acréscimos e recortes lhe são feitos para que o texto final se adeque à interpretação dos atores no palco. Dessa forma, o trabalho do ator, de acordo com Egídio Bento Filho, é "representar bem os textos que lhe são destinados" (FILHO, 2013, p. 15). Além disso, apesar de o texto fornecer ao ator os indícios de comicidade, na hora dos ensaios e na performance, o riso vai depender da performance do ator e em como ele enuncia o texto no palco.

No tocante à transposição de humor de uma língua para outra, cada tradutor trará ao texto a sua bagagem cognitiva e cultural, além da própria interpretação do texto, que pode diferir da do leitor. O humor aliado à linguagem vulgar fornece ao leitor (e, no caso do teatro, ao espectador) indicações da classe social na qual o personagem se insere. No caso da Ama, por exemplo, percebemos que é uma personagem secundária, mas é de grande importância para o enredo, uma vez que ela, assim como o clown, é responsável por dizer as verdades nuas e cruas da vida dos outros personagens com certo tom de sarcasmo, ironia e humor, e no caso do elemento tabu, este "passar a ser [...] elemento fundamental na leitura e na interpretação do caráter dos personagens" (VOLLET, 1998, p. 81), cujo linguajar faz o leitor diferir a linguagem da Ama em contraposição à de Mercúcio - que por ser nobre, usa uma linguagem mais rebuscada -, e apesar de se valer também de uma linguagem com certo teor sexual, faz parte de 
uma classe social privilegiada. Além do mais, o texto traduzido, embora não seja capaz de captar toda a "aura" que contém no texto-matriz, fará que seja apresentado um novo olhar para o autor traduzido.

\section{REFERÊNCIAS BIBLIOGRÁFICAS}

ATTARDO, Salvatore. Translation and Humour: An Approach Based on the General Theory of Verbal Humour (GTVH). In: VANDAELE, J. (ed.) The Translator: Volume 8, Number 2. Special Issue. Translating Humour. Manchester: St. Jerome Publishing, 2002, p. 173-194

BAKTHIN, Mikhail. Cultura Popular na Idade Média e no Renascimento: o contexto de François Rabelais. Coleção Linguagem e Cultura. Tradução de Yara Frateschi Vieira. São Paulo/Brasília: Editora Hucitec/Editora da UnB, 1987.

BARANCZAK, Stanislaw. How to Translate Shakespeare's Humor?: (Reflections of a Polish Translator). Performing Arts Journal, Vol. 14, nº 3, 1992, p. 70-89.

BASSNETT, Susan. Still Trapped in the Labyrinth: Further Reflections on Translation and Theatre. In: BASSNETT, Susan.; LEFEVERE, André. Constructing Cultures. Clevedon: Multilingual Matters, 1998, p. 90- 108.

BRADLEY, Andrew Cecil. Shakespearean Tragedy: Lectures on Hamlet, Othello, King Lear, Macbeth. $2^{\text {nd }}$ ed. $8^{\text {th }}$ impression. Glasgow: Glasgow University Press, 1905.

BREZOLIN, Adauri. Humor: é possível traduzi-lo e ensinar a traduzi-lo. Tradterm, São Paulo, vol. 4, nº 1, 1997.

BLY, Mary. The legacy of Juliet's desire in comedies of the early 1600s. In: ALEXANDER, Catherine M. S.; WELLS, Stanley. (eds). Shakespeare and Sexuality. $1^{\text {st }}$ edition. Cambridge: Cambridge University Press, 2001, p. 52-71.

CHIARO, Delia. Translation. In: ATTARDO, Salvatore. Encyclopedia of Humor Studies. Volume 1. USA: SageReference, 2014, p. 1394-1398.

D'ANGELI, Concetta; PADUANO, Guido. O cômico. Tradução de Caetano Waldrigues Galindo. Curitiba: Editora da UFPR, 2007.

ECO, Umberto. Quase a mesma coisa: experiências de tradução. Tradução de Eliana Aguiar. Rio de Janeiro: Editora Record, 2007.

FERNANDES, Millôr. Hamlet - a tradução. Revista 34 Letras, $\mathrm{n}^{\circ}$ 3, Rio de Janeiro: Editora 34, 1989, p. 76-80.

GODDARD, Harold. C. The Meaning of Shakespeare: Romeo and Juliet. In: BLOOM, Harold. William Shakespeare. Bloom's Modern Critical Views. Broomall: Chelsea House Publisher, 2004, p. 85- 108.

LUIIZ, CAMILOTTI. Um estudo do humor da Ama de Romeu Julieta nas traduções de Bárbara Heliodora e Beatriz Viégas-Faria

Belas Infiéis, v. 7, n. 2, p. 9-26, 2018. DOI: 10.26512/belasinfieis.v7i2.12225 
KOTT, Jon. Shakespeare: nosso contemporâneo. Tradução de Paulo Neves. São Paulo: Cosac e Naify, 2003.

LUIZ, Tiago Marques. “Cava A Cova!": Descrevendo o humor da cena dos coveiros de Hamlet em duas traduções brasileiras. 2013. 132 f. Dissertação (Mestrado em Estudos da Tradução) - Centro de Comunicação e Expressão, Universidade Federal de Santa Catarina, Florianópolis, 2013.

LUIZ, Tiago Marques. "A presença da comédia nas tragédias de Shakespeare", de Arthur Huntington Nason. Dramaturgia em foco, Petrolina, v. 1, n. 1, p. 158-169, 2017.

MARTINS, Márcia do Amaral Peixoto. A tradução dos jogos de palavras shakespearianos: o caso de A Megera Domada. In: CAMATI, Anna Stegh; MIRANDA, Célia Arns. Shakespeare sob múltiplos olhares. $2^{a}$ edição. Curitiba: Editora da UFPR, 2016, p.287-314.

MARTINS, Márcia do Amaral Peixoto. A instrumentalidade do modelo Descritivo para a análise de traduções: O caso dos Hamlets brasileiros. 1999. 318f. Tese (Doutorado em Comunicação e Semiótica). Faculdade de Filosofia, Comunicação, Letras e Artes, Pontifícia Universidade Católica de São Paulo, São Paulo, 1999.

MUÑOZ-BASOLS, Javier; MUÑOZ-CALVO, Micaela. La traducción de textos humorísticos multimodales. In: IBAÑEZ, María Azucena Penas. La traducción. Nuevos 24 planteamientos teórico- metodológicos. Madrid: Síntesis Editorial, 2015, p. 159-184.

PAVIS, Patrice. O teatro no cruzamento de culturas. Tradução de Nanci Fernandes. São Paulo: Perspectiva, 2008.

SHAKESPEARE, William. Romeo and Juliet. Fully annotated, with an introduction by Burton Raffel, with an essay by Harold Bloom. The Annotated Shakespeare. New Haven and London: Yale University Press, 2004.

SHAKESPEARE, William. Romeu e Julieta. Tradução de Bárbara Heliodora. Rio de Janeiro: Lacerda Editores, 1997.

SHAKESPEARE, William. Romeu e Julieta. Tradução de Beatriz Viégas-Faria. Porto Alegre: L\&PM Pocket, 2016.

SILVA, Marcel Veira Barreto. Adaptação intercultural: o caso de Shakespeare no cinema brasileiro. Salvador: EDUFBA; Brasília: Compós, 2013.

STEVENS, Kera; MUTRAN, Munira Hamud. Introdução. In: STEVENS, Kera; MUTRAN, Munira Hamud. O teatro inglês da Idade Média até Shakespeare. Coleção Literatura em Perspectiva. Série Inglesa. São Paulo: Global Editora, 1988, p. 9-30.

VANDAELE, Jeroen. Humor in Translation. In: GAMBIER, Yves; VAN-DOORSLAER, Luc. Handbook of Translation Studies. Volume 1. Amsterdam: John Benjamins Publishing Company, 2010, p. 147-152.

LUIIZ, CAMILOTTI. Um estudo do humor da Ama de Romeu Julieta nas traduções de Bárbara Heliodora e Beatriz Viégas-Faria

Belas Infiéis, v. 7, n. 2, p. 9-26, 2018. DOI: 10.26512/belasinfieis.v7i2.12225 


\section{VIÉGAS-FARIA, Beatriz. O que significa traduzir hoje a dramaturgia shakespeariana?.} Disponível

em:

<http://beatrizvie.dominiotemporario.com/doc/O_que_significa_traduzir_hoje_a_dramaturgia shakespeariana.pdf>. Acesso em: 03 de março de 2017.

VOLLET, Neuza Lopes Ribeiro. Nobreza vs Obscenidade em traduções brasileiras de Hamlet: uma reflexão sobre as relações possíveis entre os tradutores e seu autor. Tradterm, São Paulo, Volume 5, nº 2, 1998, p. 71-96.

WELLS, Stanley. Shakespeare, Sex, and Love. Oxford: Oxford University Press, 2010.

WILES, David. Shakespeare's Clown: Actor and Text in the Elizabethan Playhouse. Cambridge: Cambridge University Press, 2005

WILLIAMS, Gordon. A glossary of Shakespeare's sexual language. Great Britain: Biddies Ltd, 1997.

ZABALBEASCOA, Patrick. La traducción del humor en textos audiovisuales. In: DURO, Miguel. La traducción para el doblaje y la subtitulación. Colección signo e imagen, número 63. Madrid: Cátedra, 2001, p. 251-263.

\footnotetext{
${ }^{1}$ Tiago Marques LUIZ - Doutorando em Letras pela Universidade Federal de Uberlândia. Mestre em Estudos da Tradução (2013) pela Universidade Federal de Santa Catarina. Graduado em Letras - Português e Inglês pela (2009) Universidade Federal da Grande Dourados. Uberlândia, Minas Gerais, Brasil.

Lattes: http://lattes.cnpq.br/2785674972617689 E-mail: markx2006@ gmail.com

${ }^{2}$ Camila Paula CAMILOTTI - Doutora em Estudos da Tradução (2014) pela Universidade Federal de Santa Catarina. Mestre em Inglês: Estudos Linguísticos e Literários (2010). Graduada em Letras Português Inglês e suas Respectivas Literaturas pela Universidade Paranaense. Professora adjunta na Universidade Tecnológica Federal do Paraná. Pato Branco, Paraná, Brasil.

Lattes: http://lattes.cnpq.br/5635193603045624 E-mail: amilapc5@gmail.com

${ }^{3}$ Em Romeu e Julieta, apresentamos como exemplo de estrutura sintática a fala de Julieta no Ato III, Cena V: "Indeed I never shall be satisfied/ With Romeo till I behold him - dead -/ Is my poor heart so for a kinsman vex'd." Tal estrutura é complicada nesta fala da personagem, pois ela diz duas coisas simultaneamente: a) "até que eu o veja morto", o que significa que ela não descansará até ter a sua vingança, e b) "até que eu o veja, morto está meu pobre coração", trazendo o entendimento de que seu coração está morto pela ausência de Romeu e ela não descansará até vê-lo, e desta forma, Julieta mostra ser capaz de apaziguar sua mãe e trazer seus verdadeiros sentimentos nas palavras.

${ }^{4}$ As imagens se fazem presentes entre os antônimos luz e trevas, como no exemplo do Ato I, Cena V, onde Romeu diz que Julieta "is the sun" capaz de "kill the envious moon", onde os símbolos do Sol e da Lua representam este contraste.

${ }^{5}$ Como exemplo de figuras de linguagem, temos a metáfora no Ato II, Cena IV, em que Mercúcio provoca a Ama. A metáfora usada pelo jovem, de caráter obsceno, faz referência à penitência realizada no período da Quaresma: "comida de abstinência, que geralmente está seca antes de acabar", provocando a Ama por ser de idade avançada e de aspecto pouco atraente.

${ }^{6}$ Por estereótipo, trazemos o entendimento de Salvatore Attardo (2002), que os chama de Alvo (target, no original), ou seja, é aquele que será zombado, ridicularizado em um texto humorístico como a piada, por exemplo.

7 Original em inglês: "that is similar to the effect caused by the source text on the source reader even if this means forgoing formal likeness." Todas as traduções apresentadas no artigo são de nossa autoria, exceto quando informado o contrário.

${ }^{8} \mathrm{O}$ termo 'clown' no modo como usado no Brasil em inglês remete o leitor ao clown contemporâneo, porém muito tem se debatido sobre o resgate da palavra 'palhaço', o que nos leva à entender que no teatro renascentista, a figura cômica era o bobo - termo este usado nas traduções das peças shakespearianas.
}

LUIIZ, CAMILOTTI. Um estudo do humor da Ama de Romeu Julieta nas traduções de Bárbara Heliodora e Beatriz Viégas-Faria

Belas Infiéis, v. 7, n. 2, p. 9-26, 2018. DOI: 10.26512/belasinfieis.v7i2.12225 
${ }^{9}$ Original em inglês: "The theatrical fool or clown [...] was a sore trial to the cultured poet and spectator in Shakespeare's day. He came down from the Morality plays, and was beloved of the groundlings. His antics, his songs, his dances, his jests, too often unclean, delighted them, and did something to make the drama, what the vulgar, poor or rich, like it to be, a variety entertainment".

${ }^{10}$ Original em espanhol: "de producir una reacción de risa o sonrisa (de ser gracioso) en los destinatarios del texto". ${ }^{11}$ Original em inglês: "On the one hand, any translation failure will therefore be very visible: it is obvious that the translator has failed when no one laughs at translated humor. On the other hand, the translator of humor has to cope with the fact that the "rules", "expectations", "solutions" and agreements on "social play" are often group or culture-specific."

12 Original em inglês: "may be best relegated to second place behind attempts at a recreated text recognizable as humorous to target recipients."

${ }^{13}$ Original em espanhol: "(re)producir un componente o efecto humorístico, o de entretenimiento, en el texto meta con el objetivo de que el receptor se vea expuesto y perciba dicho efecto"

14 Original em espanhol: reconocer la especificidad lingüística y cultural del texto humorístico para [...], determinar cómo se pueden traducir o reconfigurar los elementos propios del acto comunicativo.

${ }^{15}$ Original em inglês: a mean of circumventing taboos, as are euphemisms, which play a similar hide-and-seek game with listener/reader.

${ }^{16}$ Original em inglês: "a coarse old woman whose loquacity makes us laugh fail hopelessly to plumb the depth of her depravity".

${ }^{17}$ Original em inglês: Stage-oriented translations

${ }^{18}$ Original em inglês: Page-oriented translations 